\title{
Effect of Osmotic Stress on the Initial Development of Bean Seedlings
}

\author{
Pablo Diego Silva Cabral ${ }^{*}$, Leonardo N. S. dos Santos², Henrique Duarte Vieira1, \\ Tais Cristina Bastos Soares ${ }^{3}$, Cintia Aparecida Bremenkamp4, Weverton Pereira Rodrigues ${ }^{1}$ \\ ${ }^{1}$ University of North Rio de Janeiro State Darcy Ribeiro, Rio de Janeiro, Brazil \\ ${ }^{2}$ Faculty of Agricultural Engineering, University of Campinas, São Paulo, Brazil \\ ${ }^{3}$ Agricultural Sciences Center, Federal University of Espírito Santo, Victoria, Brazil \\ ${ }^{4}$ Instituto Capixaba de Pesquisa e Extensão Rural-INCAPER, Victoria, Brazil \\ Email: ${ }^{*}$ pablodscabral@hotmail.com
}

Received 25 April 2014; revised 23 May 2014; accepted 14 June 2014

Copyright (C) 2014 by authors and Scientific Research Publishing Inc.

This work is licensed under the Creative Commons Attribution International License (CC BY).

http://creativecommons.org/licenses/by/4.0/

(c) (i) Open Access

\begin{abstract}
One of the methods to determine the tolerance of plants to water stress is the observation of germination of seeds under stress induced in laboratory conditions. Thus, the aim was to evaluate the response of four common bean cultivars to water deficit simulated under laboratory conditions. Two common landrace genotypes acquired from farmers (FORT 07 and FORT 08) and two commercial cultivars, IAPAR 81 and Serrano were evaluated. The different levels of water deficit were induced with mannitol solution. The experimental design was completely randomized and a factorial scheme $5 \times 4$ (osmotic potential $x$ genotypes), with four replications. The characteristics: primary root protrusion, seed vigor, normal and abnormal seedling, seedling and root length, fresh and dry weight of seedling and root were evaluated. By reducing the osmotic potential seedling vigor bean was more affected than the primary root protrusion. Regardless of cultivar, there was a significant and progressive reduction in the normal seedlings percentage from potential -0.3 MPa. The IAPAR 81 and FORT 07 cultivars showed higher tolerance to water deficit compared to other cultivars.
\end{abstract}

\section{Keywords}

Phaseolus vulgaris L., Mannitol, Water Stress

\section{Introduction}

The conditions that seeds encounter in soil are sometimes adverse, such as saline and sodic soils. The proportion

\footnotetext{
${ }^{*}$ Corresponding author.
}

How to cite this paper: Cabral, P.D.S., dos Santos, L.N.S., Vieira, H.D., Soares, T.C.B., Bremenkamp, C.A. and Rodrigues, W.P. (2014) Effect of Osmotic Stress on the Initial Development of Bean Seedlings. American Journal of Plant Sciences, 5, $1973-$ 1982. http://dx.doi.org/10.4236/ajps.2014.513211 
of saline soils has increased due to the misuse of agricultural techniques, such as excessive fertilization and irrigation with water unfit for such purpose, turning fertile and productive land into unsuitable land for agriculture [1] [2]. External factors that affect the germination process is considered as the most important seed hydration, since water is the matrix where occurs most biochemical and physiological processes that result in the primary root protrusion [3] [4].

According to [5]-[7], the growth inhibition caused by water stress is due to the osmotic effect, i.e., to dry physiological produced as the toxic effect due to the entry of ions in the seed during the imbibition. The conditions of sowing lead initially to a decrease in water uptake by seeds [8], negatively affecting vigor and germination and increasing the abnormal seedlings' percentage, thus causing, in field conditions, a decreased plants final stand and consequent reduction in productivity.

Several works on seeds of various species have been conducted under conditions of water deficit and salt stress, with the objective of determining the vigor and seed physiological quality [9]-[13]. In this sense, several osmotic solutions have been used to simulate an environment of reduced water availability, among which we can mention PEG (polyethylene glycol), mannitol, $\mathrm{CaCl}_{2}$ (calcium chloride), $\mathrm{KCl}$ (potassium chloride) and $\mathrm{NaCl}$ (sodium chloride). However, according to [14], the calcium chloride as osmotic agent, was not as efficient as mannitol. Regarding the potassium and sodium chlorides, work previously reported that solutions of these salts exhibit toxicity to bean seeds from $-0.6 \mathrm{MPa}$, not being recommended as water deficiency simulators [13]. The effects of osmotic potential on seeds and seedlings depend on the initial seed quality and type of solute used when they are subjected to the same degree of water deficit [15].

One of the most widespread methods for determining the germination and vigor plants tolerance to drought stress is the observation of seed germination under stress in laboratory conditions (Larcher, 2000 [16]). Thus, the present study aimed to evaluate the seeds physiological performance of four genotypes in simulated and standard conditions of water deficit in the laboratory.

\section{Material and Methods}

Seeds of four common bean cultivars were used, two landrace genotypes acquired from farmers in the Fortaleza locality, Muqui, Espírito Santo, Brazil (FORT 07 and 08) and two commercial cultivars (Serrano and IAPAR 81), all characterized [17] [18], as shown in Table 1.

Different mannitol solutions levels $\left(\mathrm{C}_{6} \mathrm{H}_{14} \mathrm{O}_{6}\right)$ were used to determine the water stress of the cultivars mentioned. The osmotic potential (MPa) and the concentration used was calculated by Van't Hoff's formula [19]), shown in Table 2.

Table 1. Weight of 1000 seeds in grams (P1000), growth habit (GH) and commercial group (GC) of four bean cultivars adapted by Cabral et al. (2010 and 2011).

\begin{tabular}{|c|c|c|c|}
\hline Cultivars & P1000 & GH & CG \\
\hline Serrano & 160.4 & II & Black \\
\hline IAPAR 81 & 209.2 & II & Carioca \\
\hline FORT 07 & 197.7 & III & Rosinha \\
\hline FORT 08 & 413.7 & III & Jalo \\
\hline
\end{tabular}

GH: II = indeterminate growth, upright plant architecture, III = indeterminate growth, prostrate cowpea.

Table 2. Mannitol concentrations to obtain different osmotic potential levels.

\begin{tabular}{cc}
\hline Level (MPa) & Mannitol concentration $\left(\mathbf{g} \cdot \mathbf{L}^{-\mathbf{1}}\right)$ \\
\hline 0.0 & 0.0 \\
-0.3 & 22.36 \\
-0.6 & 44.73 \\
-0.9 & 67.09 \\
-1.2 & 89.46 \\
\hline
\end{tabular}


For the germination test was used four replicates with fifty seeds, which were distributed equidistant along two longitudinally lines in the upper two thirds of the paper roll germitest, being two leaves like basis and a to cover. The leaves were moistened with 2.5 times its mass with mannitol solutions (Table 2). Subsequently, this set was wrapped in polyethylene bags and placed in a germination chamber at a constant temperature of $25^{\circ} \mathrm{C}$. The Counts were performed at five and nine days [20].

Vigor was evaluated by the first germination count found on the 5th day after sowing, the classification "strong normal" encompasses the seedlings that were well developed and perfect morphologically, but "weak normal" were considered perfect morphologically seedlings, but with less development than "strong normal". Abnormal seedlings were those which not show potential to continue its development and generate a normal plant. Seedlings that did not meet these requirements remained in testing until the final count (9th day), at which time all remaining seedlings were evaluated as normal and abnormal. We also assessed the percentage of seeds that issued the primary root (PRP).

To determine the radicle length and seedling were used 20 seedlings per replicate of each genotype evaluated at the final count with the aid of a ruler graduated in millimeters. These same seedlings were used to evaluate the fresh and dry weight of radicle and seedling. The parties were sectioned and placed separately in paper bags properly identified, which were put to dry in an oven at $60^{\circ} \mathrm{C}$ for 48 hours. After this period, the materials were placed in a desiccator to cool and then weighed on an analytical balance accurate to $0.001 \mathrm{~g}$.

The experimental design was completely randomized, being conducted in a factorial scheme $5 \times 4$ (osmotic potential $x$ genotypes), with four replications with fifty seeds. The results of the primary root protrusion, first count (vigor), normal and abnormal seedlings were transformed into arcsine $(\mathrm{X} / 100)^{0.5}$. After, we proceeded to the analysis of variance and Tukey test with the GENES software [21]. To perform polynomial regressions for the different osmotic potential levels evaluated used the Sigma Plot software 11.0.

\section{Results and Discussion}

By analysis of variance was observed that among the cultivars there was significant difference for the vigor, SFM, RFM, SDM and RDM (Table 3), demonstrating differential response of these genotypes when subjected

Table 3. Analysis of variance and mean test first count (Vigor), primary root protrusion (PRP), abnormal (AP) and normal (NP) seedlings percentage, seedling (SL) and root length (RL), seedling (SFW) and root (RFW) fresh weight, seedling (SDW) and root (RDW) dry weight to cultivate and osmotic potential (OP).

\begin{tabular}{|c|c|c|c|c|c|c|c|c|c|c|}
\hline \multirow{2}{*}{ SV } & Vigor (\%) & PRP (\%) & AP (\%) & NP (\%) & SL (cm) & RL (cm) & SFW (g) & RFW (g) & SDW (g) & RDW (g) \\
\hline & \multicolumn{10}{|c|}{----------------------Mean squares--------------------- } \\
\hline Cultivar & $10.78^{*}$ & $0.54^{\mathrm{ns}}$ & $26.3^{\text {ns }}$ & $28.3^{\text {ns }}$ & $10.68^{\text {ns }}$ & $1.44^{\mathrm{ns}}$ & $167.5^{* *}$ & $2.38^{* *}$ & $6.21^{* *}$ & $0.034^{* *}$ \\
\hline $\mathrm{OP}$ & $128^{* *}$ & $115^{* *}$ & $524^{* *}$ & $1111^{* *}$ & $324^{* *}$ & $85.6^{* *}$ & $31.1^{*}$ & $1.81^{*}$ & $0.97^{* *}$ & $0.017^{*}$ \\
\hline CV (\%) & 4.23 & 2.17 & 31.06 & 8.67 & 14.71 & 17.13 & 17.73 & 23.07 & 16.34 & 26.93 \\
\hline \multicolumn{11}{|l|}{ Cultivar } \\
\hline Serrano & 60.3 a & 96.0 a & $42.70 \mathrm{a}$ & $57.30 \mathrm{a}$ & $9.61 \mathrm{a}$ & 9.27 a & $6.14 \mathrm{~b}$ & $0.89 \mathrm{~b}$ & $1.02 \mathrm{~b}$ & $0.121 \mathrm{~b}$ \\
\hline IAPAR 81 & 59.4 a & $96.2 \mathrm{a}$ & 39.88 a & 60.12 a & 10.09 a & 9.27 a & $7.29 \mathrm{~b}$ & $1.13 \mathrm{~b}$ & $1.18 \mathrm{~b}$ & $0.117 \mathrm{~b}$ \\
\hline FORT 07 & $49.8 \mathrm{~b}$ & $95.5 \mathrm{a}$ & $44.65 \mathrm{a}$ & $55.34 \mathrm{a}$ & $10.86 \mathrm{a}$ & 9.07 a & $8.13 \mathrm{~b}$ & $1.25 \mathrm{ab}$ & $1.30 \mathrm{~b}$ & $0.142 \mathrm{ab}$ \\
\hline FORT 08 & $44.4 \mathrm{c}$ & $96.2 \mathrm{a}$ & $42.76 \mathrm{a}$ & $57.24 \mathrm{a}$ & $8.61 \mathrm{a}$ & $8.70 \mathrm{a}$ & $12.74 \mathrm{a}$ & $1.71 \mathrm{a}$ & $2.26 \mathrm{a}$ & $0.207 \mathrm{a}$ \\
\hline \multicolumn{11}{|l|}{$\mathrm{OP}$} \\
\hline 0.0 & $83.0 \mathrm{a}$ & $100 \mathrm{a}$ & $11.0 \mathrm{~d}$ & $89.0 \mathrm{a}$ & $15.6 \mathrm{a}$ & $10.7 \mathrm{ab}$ & 10.91 a & $1.69 \mathrm{a}$ & $1.83 \mathrm{a}$ & $0.195 a$ \\
\hline-0.3 & 78.7 a & $100 \mathrm{a}$ & $11.3 \mathrm{~d}$ & 88.6 a & $12.1 \mathrm{~b}$ & $11.42 \mathrm{a}$ & $9.02 \mathrm{ab}$ & $1.30 \mathrm{~b}$ & $1.60 \mathrm{ab}$ & $0.162 \mathrm{ab}$ \\
\hline-0.6 & $64.3 \mathrm{~b}$ & 99.5 a & $34.0 \mathrm{c}$ & $66.0 \mathrm{~b}$ & $10.3 \mathrm{~b}$ & $9.94 \mathrm{ab}$ & $8.44 \mathrm{ab}$ & $1.22 \mathrm{~b}$ & $1.38 \mathrm{~b}$ & $0.147 \mathrm{ab}$ \\
\hline-0.9 & $40.0 \mathrm{c}$ & $91.6 \mathrm{~b}$ & $56.6 \mathrm{~b}$ & $43.3 \mathrm{c}$ & $6.2 \mathrm{c}$ & 7.22 bc & $7.95 \mathrm{ab}$ & $1.06 \mathrm{bc}$ & $1.28 \mathrm{bc}$ & $0.125 \mathrm{~b}$ \\
\hline-1.2 & $1.25 \mathrm{~d}$ & $88.7 \mathrm{~b}$ & $99.5 \mathrm{a}$ & $0.5 \mathrm{~d}$ & $4.5 \mathrm{c}$ & $6.04 \mathrm{c}$ & $6.56 \mathrm{~b}$ & $0.95 \mathrm{c}$ & $1.12 \mathrm{c}$ & $0.103 \mathrm{c}$ \\
\hline
\end{tabular}

${ }^{\mathrm{ns}}$ not significant, ${ }^{*}$ and ${ }^{* *}$ significant at 5 and $1 \%$ probability, respectively by $\mathrm{F}$ test. $\mathrm{CV}=$ variation of coefficient. SV = source of variation. Means followed by the same letter in vertical do not differ by Tukey test at $5 \%$ probability. 
to water stress. Among the osmotic potential, there was a significant difference for all variables, which shows that different osmotic potential used to decrease water availability for seed promoted different responses at different water stress levels induced between the genotypes in study.

For vigor classifying, Machado [12] reported values of $22 \%$ at the potential of $-0.6 \mathrm{MPa}$ for the same potential an average value of $64.38 \%$ was observed (Table 3). What would indicate that the genotypes tested in this study would be more tolerant to water deficit, or can be related to the initial seed vigor in zero osmotic potential.

With increased of water restriction level, the vigor (first count) was reduced (Figure 1(a)), which is most affected from the potential -0.3 MPa in all cultivars, as previously observed [9]. These results corroborate with the findings in Table 3, where the potential 0 and $-0.3 \mathrm{MPa}$ did not differ statistically, but from $-0.3 \mathrm{MPa}$ there is a significant reduction in vigor.

Among the genotypes, the commercial cultivars achieved greater vigor compared to local genotypes (Table 3). In the zero potential IAPAR 81 had the highest value (91\%) and low vigor was determined in FORT 07 (74.5\%). However, on average, the lowest vigor observed was in the cultivar FORT 08 (Table 3), a fact that may be due to larger grain weight of this cultivar (Table 1), which corroborates, in part, to the work [22] reported a high negative correlation between the weight of 1000 seeds and beans vigor, i.e., the higher the seed, the smaller the vigor, since higher seeds germinate more slowly, since they require more water to achieve minimum moisture to activate germination process. From the potential -0.3 to $-0.9 \mathrm{MPa}$ commercial cultivars and FORT 07 obtained a lower loss of vigor (Figure 1(a)), demonstrating, in relation to other genotype under study FORT 08, greater tolerance the water availability reduction in the middle.

The primary root protrusion (PRP) was reduced according reduced the osmotic potential of the solution independent of the genotype (Figure 1(b)), the highest percentage of PRP was obtained at concentrations of 0.0, -0.3 and $-0.6 \mathrm{MPa}$ (Table 3), independent of cultivar, similar to that observed by [10] for bean seeds.

The vigor reduction was more drastic than the primary root protrusion, and this difference increased with decreasing osmotic potential (Figure 1), corroborating [9] [10] [15]. This indicates that even the potential tested, the seeds emit the primary root, but the seedlings have their development compromised by water deficit.

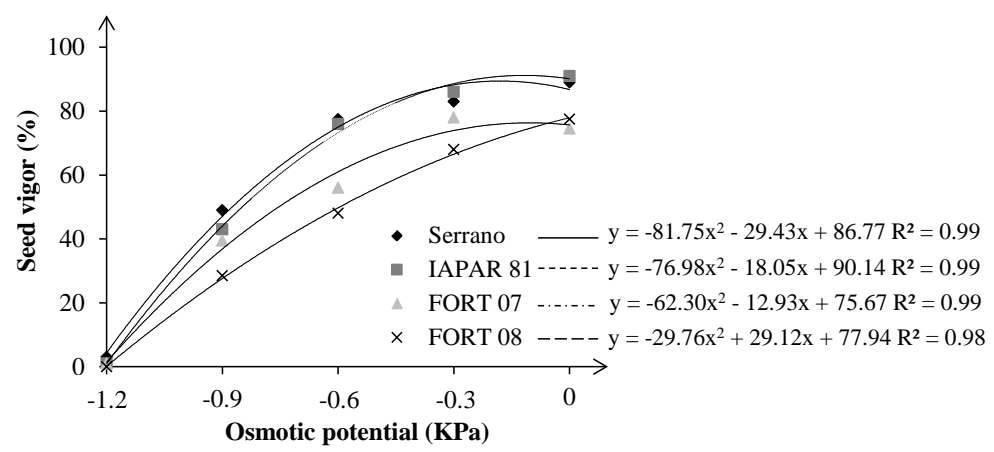

(a)

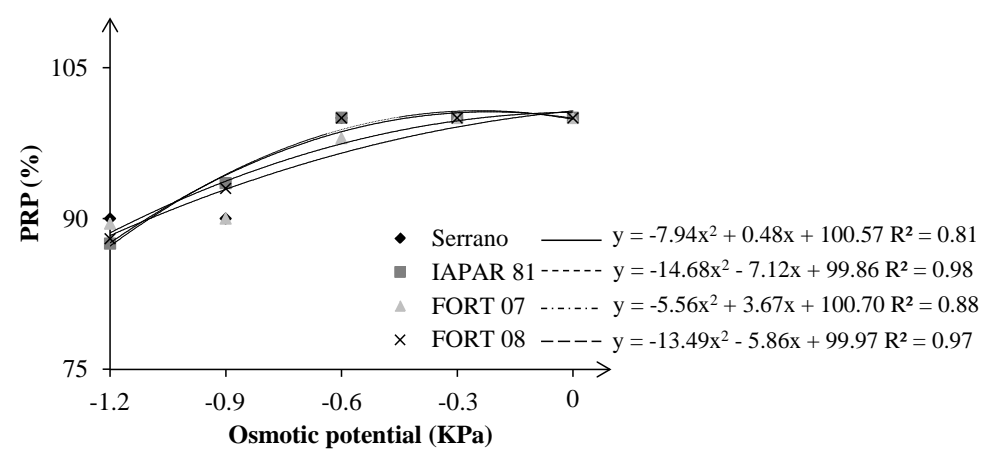

(b)

Figure 1. First count-Seed vigor (a); and primary root protrusion—PRP (b), in percentage of common seeds bean under different osmotic stress levels. 


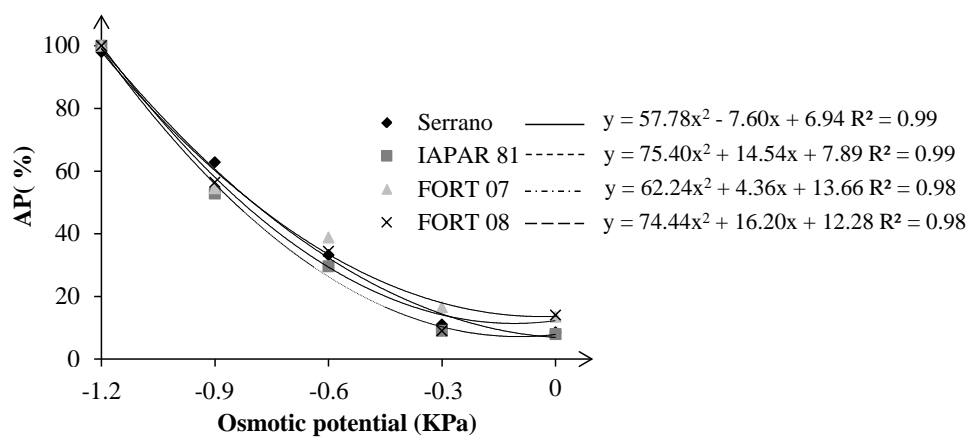

(a)

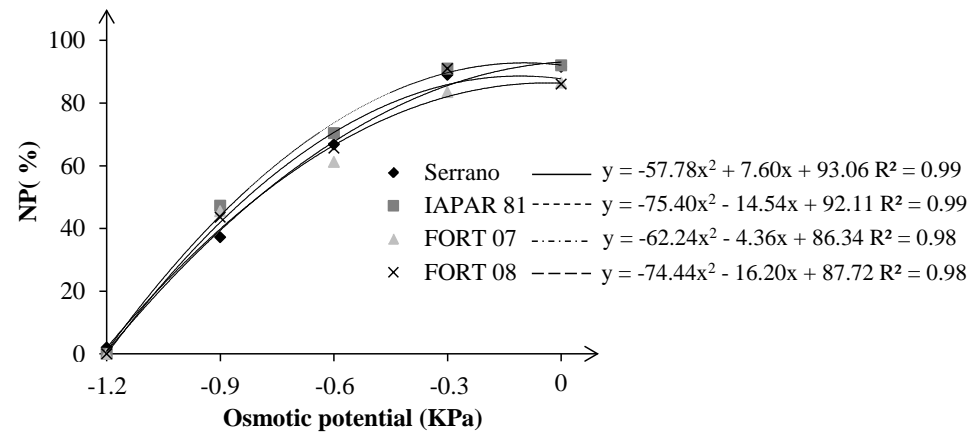

(b)

Figure 2. Abnormal seedlings-AP (a); and normal seedlings-NP (b); in percentage (\%), of bean seedlings grown under different osmotic stress levels.

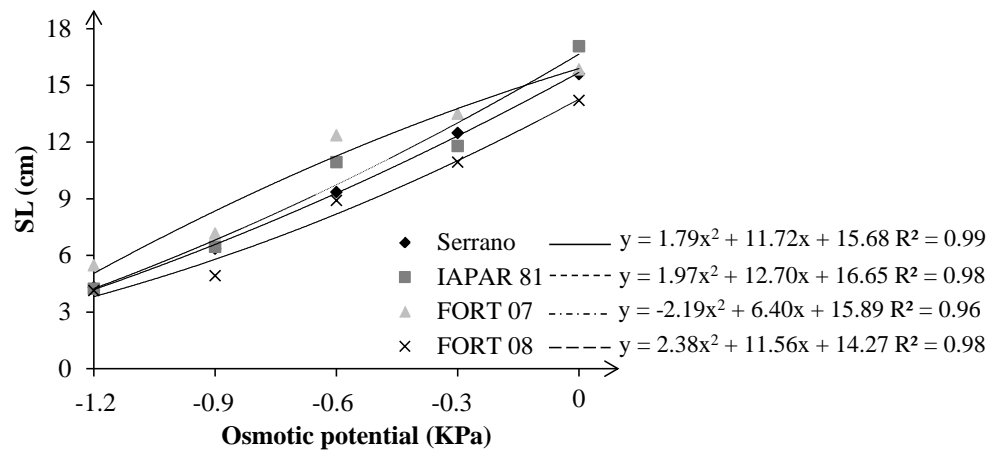

(a)

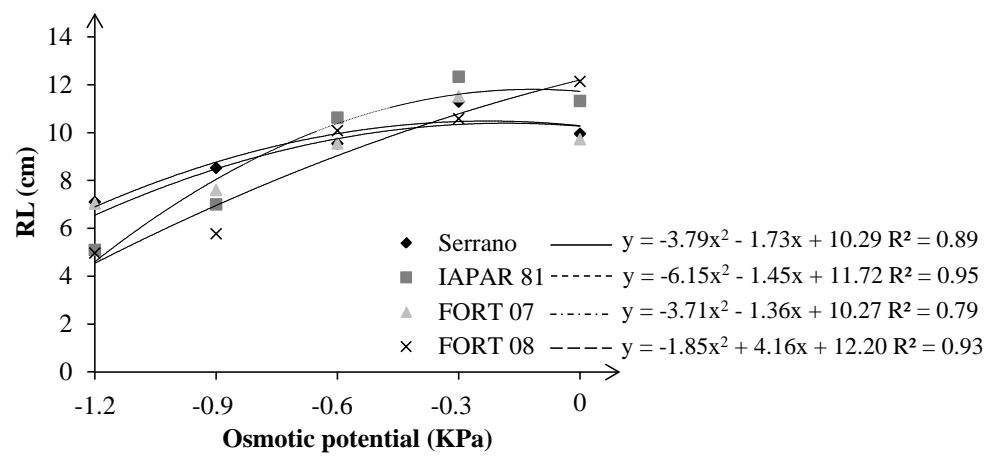

(b)

Figure 3. Seedling length—SL (a); and root length—RL (b); in centimeter $(\mathrm{cm})$, of the bean seedlings grown under different osmotic stress levels. 
For abnormal seedlings variable (AP), from zero osmotic potential to $-0.3 \mathrm{MPa}$ the percentage of abnormal seedlings remained at around 10\%, regardless of genotype (Figure 2(a)). However, we noted a dramatic increase for all genotypes, of AP percentage from potential -0.3 MPa reaching near $100 \%$ in potential $-1.2 \mathrm{MPa}$ (Table 3). Similar results were observed by [15] working with $\mathrm{NaCl}$ in bean seeds.

For normal seedlings indices (NP) at zero osmotic potential, the best average was obtained by IAPAR 81 with 92\%, followed by Serrano (91.5\%), FORT 07 (86.5\%) and FORT 08 (86\%), in which we observed the lowest average obtained for genotypes (Figure 2(b)). However, from the potential - $0.3 \mathrm{MPa}$ there was a drastic reduction of normal seedlings, reaching near zero in the potential -1.2 MPa, regardless of genotype (Table 3).

In a study conducted by [18], the substrate water potentials -0.4 and $-0.6 \mathrm{MPa}$ caused significant reduction in normal seedlings and increased percentage of abnormal seedlings in seed bean cv. IAC-Carioca, corroborating the results obtained in this experiment.

According to [23], when seeds hydration is slow, they are more vulnerable to the attack of pathogens due to ions, sugars and fatty acids exudation by seed. Thus, increasing the abnormal percentage with decreased osmotic potential can be enhanced by pathogens emergence, especially in the lower substrate water potential (unpublished data).

The seedling length (SL) decreased according to the decrease the solution osmotic potential, regardless of genotype (Figure 3(a)). In the Zero concentration the SL average was $15.67 \mathrm{~cm}$ higher than the other potential, being the lowest average $(4.53 \mathrm{~cm})$, observed in the osmotic potential of $-1.2 \mathrm{MPa}, 3.46$ times smaller than at zero potential.

In a study conducted by [12] with mannitol solution, they observed at osmotic potentials -0.6 and $-1.2 \mathrm{MPa}$ values of 4.093 and $4.043 \mathrm{~cm}$ for seedling length respectively, these being lower than those observed in this experiment. Analyzing the same variable, the highest values potential equal to $4.78 \mathrm{~cm}$ to $-0.01 \mathrm{~cm}$ to $1.24 \mathrm{MPa}$ and -0.2 MPa were observed [19], values are also lower than those observed in this experiment. However, it is noteworthy the difference between the methodologies used to measure the seedling length, since both authors evaluated the SL at fifth day after the experiment was established and this work was on the ninth day.

The root length (RL) decreased with the osmotic potential reduction, although the Serrano, IAPAR 81 and FORT 07 showed root length in the potential $-0.3 \mathrm{MPa}$ greater than at zero potential. Similar results were observed with mannitol in beans and canola [8] [19]. This effect is due to the fact that seedlings subjected to water stress, to some extent, are stimulated to greater root development allowing absorb water at greater depths [8].

In the zero osmotic potential, the best averages of RL were obtained by FORT 08 and IAPAR 81, with 12.23 and $11.72 \mathrm{~cm}$, respectively (Figure 3(b)). However, osmotic potential $-0.3 \mathrm{MPa}$ inversion occurred between these two genotypes (FORT 08 and IAPAR 81). From potential -0.3 MPa there was a drastic decrease of RL (Table 3), especially for IAPAR 81 and FORT 08, being the smallest reduction in RL for Serrano and FORT 07 which reached 8.52 and $7.59 \mathrm{~cm}$, respectively (Figure 3(b)). Thus, FORT 08 and IAPAR 81 genotypes demonstrating greater sensitivity for initial root development and Serrano and FORT 07 showed greater tolerance for osmotic potential reduce of the root development environment.

For root length variable, another work [12] obtained on the potential of -0.6 MPa, mannitol, a mean value of $12.27 \mathrm{~cm}$ and $-1.2 \mathrm{MPa} 7.44 \mathrm{~cm}$, value higher than those observed in this experiment being 9.94 and $6.04 \mathrm{~cm}$ for the potentials of -0.6 and $-1.2 \mathrm{MPa}$, respectively. On the $-0.01 \mathrm{MPa}$ value of $7.46 \mathrm{~cm}$ and $-0.2 \mathrm{MPa}, 2.07$ $\mathrm{cm}$ were observed [19], while the potential -0.4 and $-0.6 \mathrm{MPa}$ were similar, averaging $0.56 \mathrm{~cm}$ and $0.94 \mathrm{~cm}$, respectively, lower than those observed in this experiment values, indicating wide variation in different genotypes responses.

For seedlings fresh weight variable (SFW) in the stress conditions absence (Figure 4(a)), it was observed that the highest average was obtained by FORT 08 with 16.85 g, much higher than the lowest average that was obtained by Serrano (6.91 g). The FORT 08 genotype showed the best average and Serrano and the worst in all osmotic potentials. This can be explained by the fact that FORT 08 has higher seed 1000 weight $(413.7 \mathrm{~g})$ and the Serrano have lowest (160.4 g), as shown in Table 1. Accordingly, the higher the bean seed greater is the amount of reserve substances and thus, the greater the seedlings fresh weight due to the greater ability to compete for water with the environment, since the more cotyledons reservations greater the difference in water potential with the environment. However, proportionally, the greatest reduction in SFW compared to zero osmotic potential to -1.2 MPa was observed for IAPAR 81 with $-47.02 \%$, followed by FORT 08, Serrano and FORT 07, with $-45.93 \%,-31.98 \%$ and $-27.47 \%$, respectively. This demonstrates a greater sensitivity IAPAR 81 and greater tolerance for FORT 07 in relation to the SFW as the water environment reduction. 


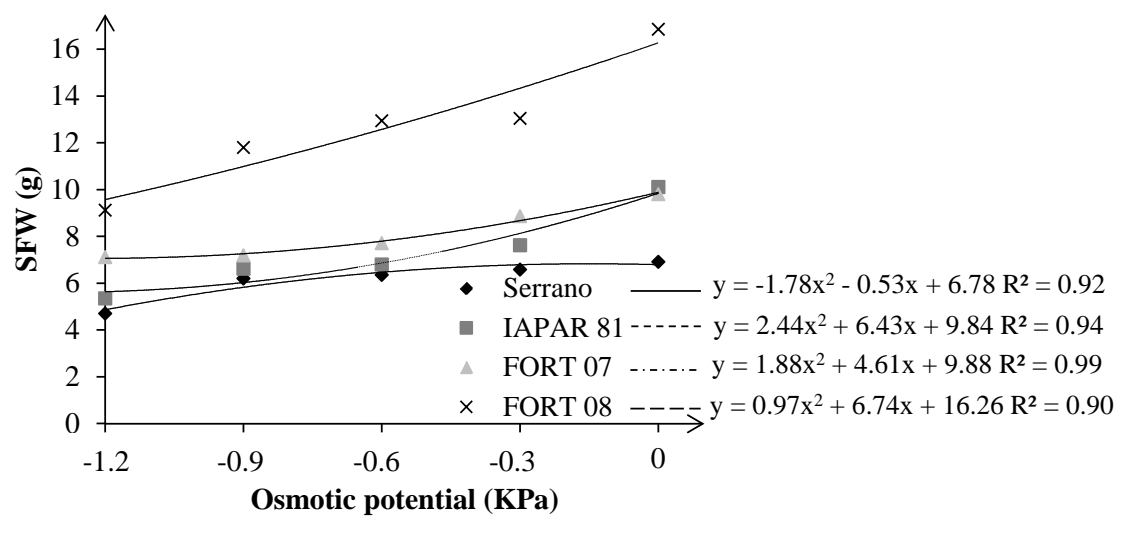

(a)

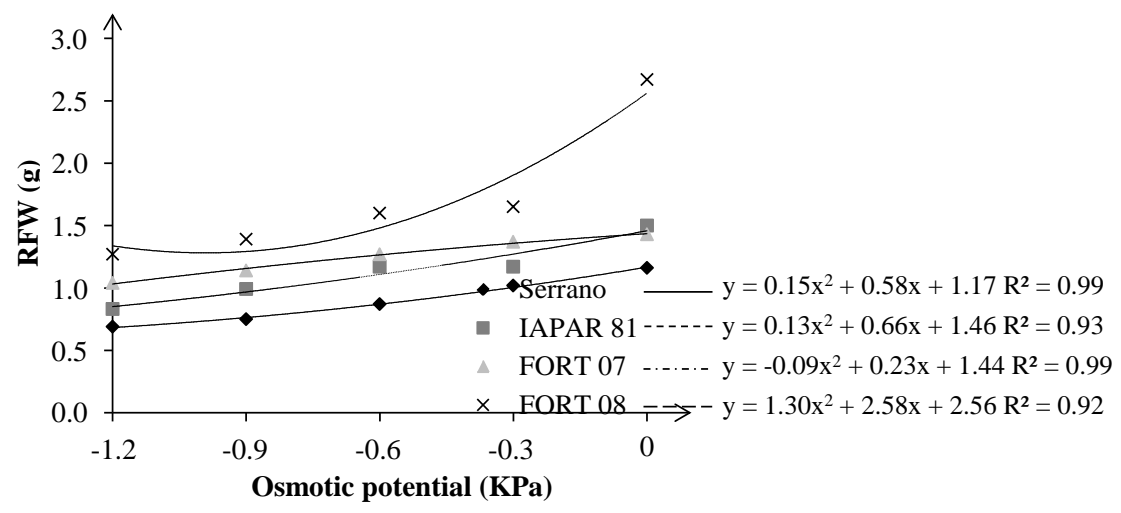

(b)

Figure 4. Seedling fresh weight-SFW (a); and root fresh weight-RFW (b); in grams (g), of the bean seedlings grown under different osmotic stress levels.

By analyzing the results of root fresh weight (RFW), it was noted that the FORT 08 and Serrano presents the highest and smaller values, respectively, regardless of the osmotic potential (Figure 4(b)), as was also observed for the SFW variable. The greatest percentage reduction between zero and $-1.2 \mathrm{MPa}$ potential was observed in the FORT 08 with $-52.43 \%$ followed by IAPAR 81 (-44.66\%), Serrano $(-40.51 \%)$ and FORT $07(-27.27 \%)$. This demonstrates that for this variable, the greater susceptibility of genotype FORT 08 and greater tolerance of FORT 07 when subjected to osmotic potential environment reduction.

The seedling (SDW) and root (RDW) dry weight variable, suffered interference of osmotic potential, with lower values for the lower potential (Figure 5), as observed by [9] [12] [19] [24].

For SDW and RDW, the best results were obtained for the FORT 08, independent of water potential (Figure 5(a) and Figure 5(b)). Serrano was more sensitive than other genotypes to water stress in higher mannitol concentration, since presented in the lower SDW at potential -1.2 $\mathrm{MPa}$.

The shoot and root bean dry weight obtained for the osmotic potential $-1.2 \mathrm{MPa}, 0.100$ and $0.057 \mathrm{~g}$, respectively [12], lower than those observed in this work, and in the same osmotic potential, it was 1.12 and $0.10 \mathrm{~g}$ for SDW and RDW, respectively.

As can be seen in this study, there are osmotic potential levels causing decrease in seed performance, becoming critical for the seedlings development. The results reveal the importance of assessment of substrate water potential, considered critical for germination and seed vigor and seedling establishment beans, beyond the need for cultivars careful selection that can present tolerance to stress conditions caused by salinity environment.

\section{Conclusions}

The osmotic potential environment decrease from $-0.3 \mathrm{MPa}$ affect the bean seeds performance of the tested genotypes. 


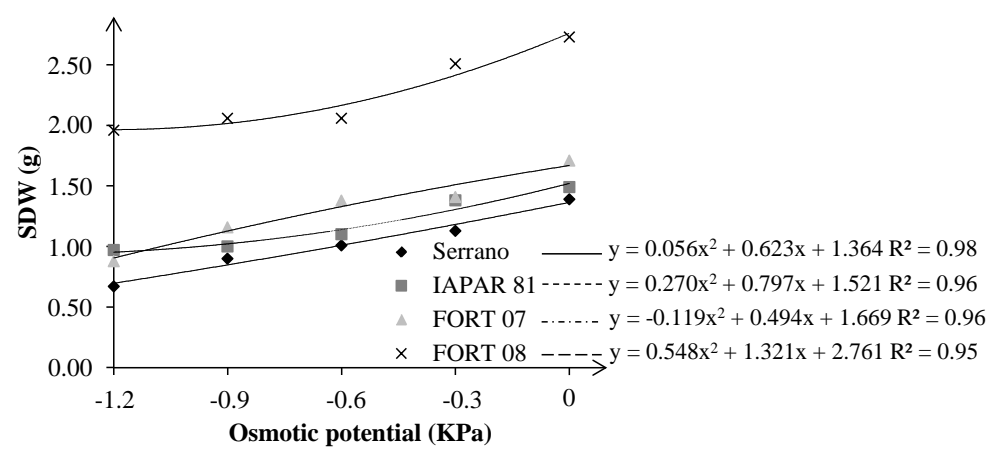

(a)

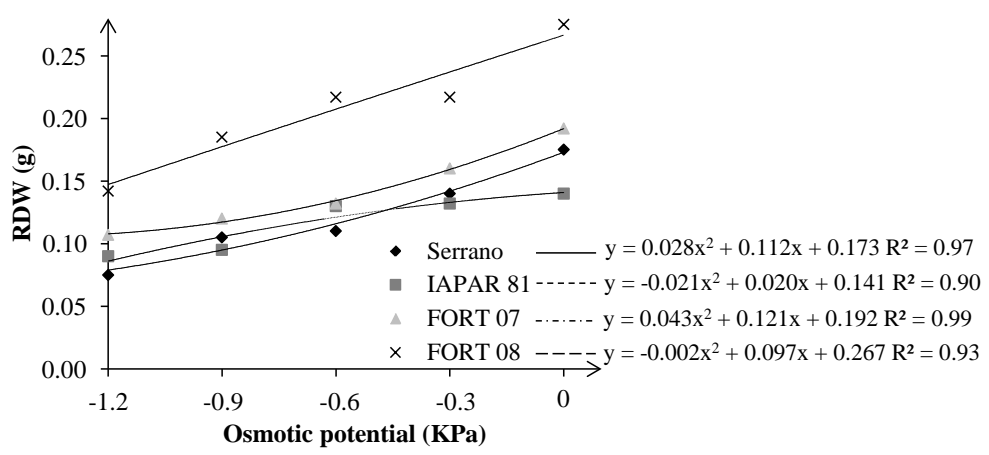

(b)

Figure 5. Seedling dry weight-SDW (a); and root dry weight-RDW (b); in grams (g), of bean seedlings grown under osmotic stress levels.

The IAPAR 81 and FORT 07 showed higher tolerance to drought stress when compared to Serrano and FORT 08.

\section{References}

[1] Amorim, J.R.A., Fernandes, P.D., Gheyi, H.R. and Azevedo, N.C. (2002) Effect of Irrigation Water Salinity and Its Mode of Application on Garlic Growth and Production. Pesquisa Agropecuária Brasileira, 37, 167-176.

[2] Ferreira, G.S., Torres, S.B. and Costa, A.R.F.C. (2007) Germination and Initial Development Stage of Melon Seedlings at Different Levels of Salinity of Irrigation Water. Caatinga, 20, 181-185.

[3] Munns, R. (2002) Comparative Physiology of Salt and Water Stress. Plant, Cell and Environment, 28, $239-250$. http://dx.doi.org/10.1046/j.0016-8025.2001.00808.x

[4] Silva, L.S., Silva, R.B., Valadares, R.N., Matos, V.P. and Lima, C.R. (2012) Behavior of Rice Seed under Different Osmotic Potentials. Revista Tropica: Ciências Agrárias e Biológicas, 6, 37-44.

[5] Andréo-Souza, Y., Pereira, A.L., Silva, F.F.S., Riebeiro-Reis, R.C., Evangelista, M.R.V., Castro, R.D. and Dantas, B.F. (2010) Effect of Salinity on Physic Nut (Jatropha curcas L.) Seed Germination and Seedling Initial Growth. Revista Brasileira de Sementes, 32, 83-92.

[6] Lacerda, C.F., Cambraia, J., Oliva, M.A. and Ruiz, H.A. (2003) Osmotic Adjustment in Roots and Leaves of Two Sorghum Genotypes under NaCl Stress. Brazilian Journal of Plant Physiology, 15, 113-118. http://dx.doi.org/10.1590/S1677-04202003000200007

[7] Oliveira, F.R.A., Oliveira, F.A., Guimarães, I.P., Medeiros, J.F., Oliveira, M.K.T., Freitas, A.V.L. and Medeiros, M.A. (2009) Emergency of Seedlings of Moringa Oleifera Lam Irrigated with Water of Different Levels of Salinity. Bioscience Journal, 25, 66-74.

[8] Ávila, M.R., Braccini, A.L., Scapim, C.A., Fagliari, J.R. and Santos, J.L. (2007) Influence of Manitol-Induced Water Stress on Canola Seed Germination and Seedling Growth. Revista Brasileira de Sementes, 29, 98-106. http://dx.doi.org/10.1590/S0101-31222007000100014

[9] Coelho, D.L.M., Agostini, E.A.T., Guaberto, L.M., Machado Neto, N.B. and Custódio, C.C. (2010) Differential Protein Expression during Germination as a Result of a Water Deficit Associated with Variable Osmotic Pressure in Snap- 
Beans. Acta Scientiarum Agronomy, 32, 491-499.

[10] Custódio, C.C., Salomão, G.R. and Machado Neto, N.B. (2009) Water Deficiency during Bean Seed Germination Induced by Different Osmotic Solutions. Revista Ciência Agronômica, 40, 617-623.

[11] Forti, V.A., Cicero, S.C. and Pinto, T.L.F. (2009) Influence of Water Availability of the Substratum and Moisture Content of the Bean Seeds on the Germination. Revista Brasileira de Sementes, 31, 63-70. http://dx.doi.org/10.1590/S0101-31222009000200007

[12] Neto, N.B.M., Custódio, C.C., Costa, P.R. and Doná, F.L. (2006) Water Stress Induced by Different Osmotic Agentes on Germination and Vigor of Bean Seeds. Revista Brasileira de Sementes, 28, 142-148. http://dx.doi.org/10.1590/S0101-31222006000100020

[13] Moterle, L.M., Lopes, P.C., Braccini, A.L. and Scapim, C.A. (2006) Germination of Seeds and Seedling Growth of Popcorn Cultivars under Water and Salinity Stress. Revista Brasileira de Sementes, 28, 169-176. http://dx.doi.org/10.1590/S0101-31222006000300024

[14] Costa, P.R. (2006) Water Defficit: Osmotic Agents and Seed Size Study. Master’s Thesis, Universidade do Oeste Paulista, São Paulo.

[15] Moraes, G.A.F., Menezes, N.L. and Pasqualli, L.L. (2005) Bean Seed Performance under Different Osmotic Potentials. Ciência Rural, 35, 776-780. http://dx.doi.org/10.1590/S0103-84782005000400004

[16] Larcher, W. (2000) Plant Ecology. Rima, São Carlos.

[17] Cabral, P.D.S., Soares, T.C.B., Gonçalves, L.S.A., Amaral Júnior, A.T., Lima, A.B.P., Rodrigues, R. and Matta, F.P. (2010) Quantification of the Diversity among Common Bean Accessions Using Ward-MLM Strategy. Pesquisa Agropecuária Brasileira, 45, 1124-1132.

[18] Cabral, P.D.S., Soares, T.C.B., Lima, A.B.P., Miranda, F.D., Souza, F.B. and Gonçalves, L.S.A. (2011) Genetic Diversity in Local and Commercial Dry Bean (Phaseolus vulgaris) Accessions Based on Microsatellite Markers. Genetics and Molecular Research, 10, 140-149. http://dx.doi.org/10.4238/vol10-1gmr993

[19] Braga, L.F., Sousa, M.P., Braga, J.F. and Sá, M.A.E. (1999) Relationship among Physiological Quality and Water Availability of Bean Seeds on the Germination Process. Revista Brasileira de Sementes, 21, 95-102.

[20] Brasil, Ministério da Agricultura Agropecuária e Abastecimento (2009) Secretaria de Defesa Agropecuária. Regras para Análise de Sementes, Brasília.

[21] Cruz, C.D. (2013) GENES-A Software Package for Analysis in Experimental Statistics and Quantitative Genetics. Acta Scientiarum. Agronomy, 35, 271-276.

[22] Coelho, C.M.M., Mota, M.R., Souza, C.A. and Miquelluti, D.J. (2010) Physiological Potential of Common Landrace Bean Seeds (Phaseolus vulgaris L.). Revista Brasileira de Sementes, 2, 97-105.

[23] Pereira, L.A.G., Costa, N., Almeida, A.M.R., Silva, C.M. and Sartori, J.F. (1981) Interaction Effect of Chemical Treatment of Soybean Seeds and Vigor Levels. Fitopatologia Brasileira, 6, 159-1631.

[24] Neto, N.B.M., Saturnino, S.M., Bomfim, D.C. and Custódio, C.C. (2004) Water Stress Induced by Mannitol and Sodium Chloride in Soybean Cultivars. Brazilian Archives of Biology and Technology, 47, 521-529.

http://dx.doi.org/10.1590/S1516-89132004000400004

\section{Abbreviations List}

AP: abnormal seedlings

$\mathrm{CaCl}_{2}$ : calcium chloride

$\mathrm{CV}$ : variation of coefficient.

GC: commercial group

GH: growth habit

IAC: Agronomic Institute of Campinas

$\mathrm{KCl}$ : potassium chloride

Mpa: megapascal

$\mathrm{NaCl}$ : sodium chloride

NP: normal seedlings

OP: osmotic potential 
P1000: weight of 1000 seeds PEG: polyethylene glycol

PRP: primary root protrusion

RDW: root dry weight

RFW: root fresh weight

RL: root length

SDW: Seedling dry weight

SFW: seedling fresh weight

SL: seedling length

SV: source of variation

Vigor: first count 
Scientific Research Publishing (SCIRP) is one of the largest Open Access journal publishers. It is currently publishing more than 200 open access, online, peer-reviewed journals covering a wide range of academic disciplines. SCIRP serves the worldwide academic communities and contributes to the progress and application of science with its publication.

Other selected journals from SCIRP are listed as below. Submit your manuscript to us via either submit@scirp.org or Online Submission Portal.
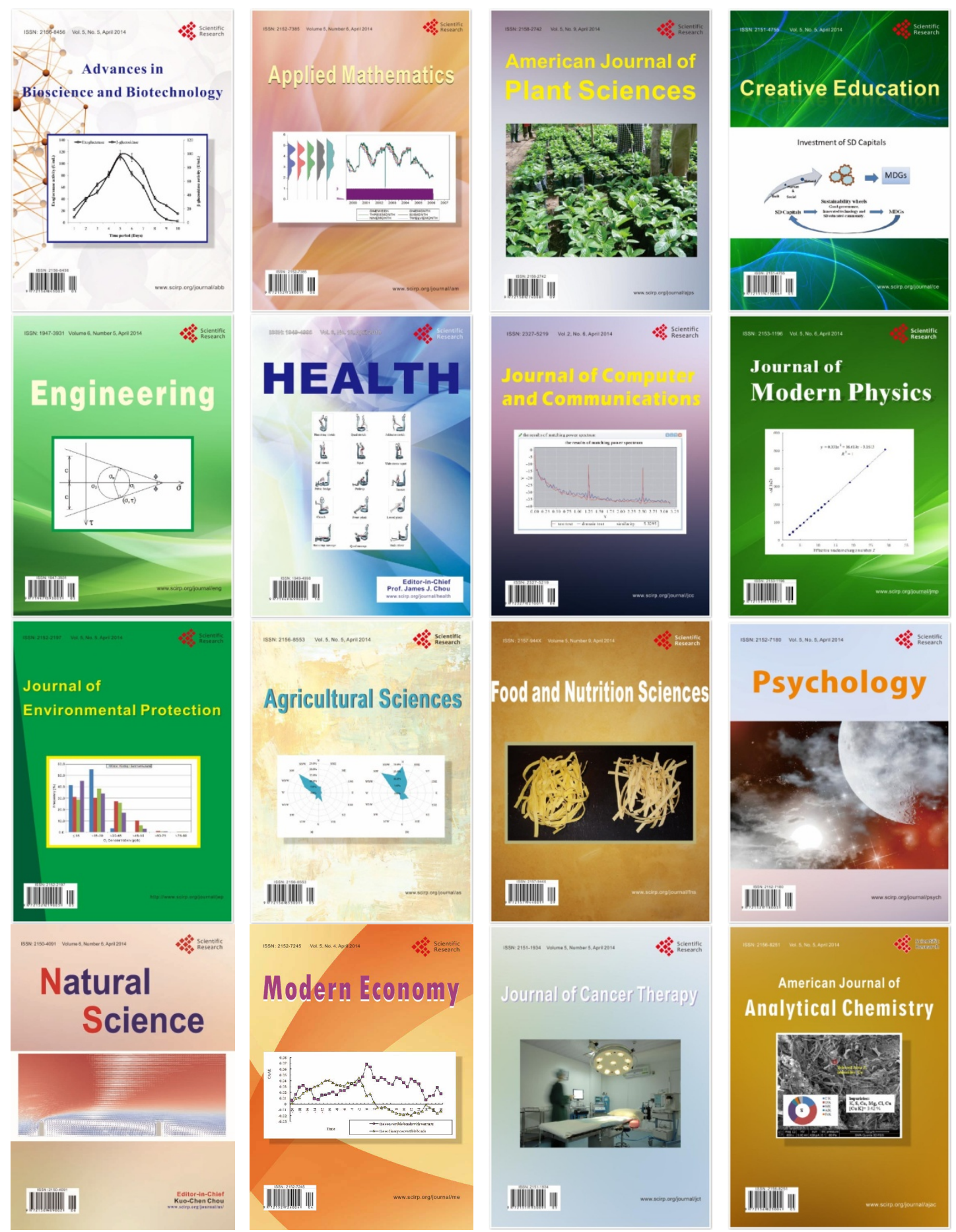